Article

\title{
Social Vulnerability, Gender and Disasters. The Case of Haiti in 2010
}

\author{
Mar Llorente-Marrón ${ }^{1, *}$, , Montserrat Díaz-Fernández ${ }^{1}\left(\mathbb{D}\right.$, Paz Méndez-Rodríguez $^{1}{ }^{(\mathbb{D}}$ and \\ Rosario González Arias 2 (D) \\ 1 Department of Quantitative Economics, University of Oviedo, 33006 Oviedo, Spain; \\ mdiaz@uniovi.es (M.D.-F.); mpmendez@uniovi.es (P.M.-R.) \\ 2 Department of Sociology, University of Oviedo, 33006 Oviedo, Spain; gonzalezrosario@uniovi.es \\ * Correspondence: mmarron@uniovi.es
}

Received: 8 March 2020; Accepted: 24 April 2020; Published: 28 April 2020

\begin{abstract}
The study of vulnerability constitutes a central axis in research work on sustainability. Social vulnerability (SV) analyzes differences in human capacity to prepare, respond and recover from the impact of a natural hazard. Although disasters threaten all the people who suffer from them, they do not affect all members of society in the same way. Social and economic inequalities make certain groups more vulnerable. Factors such as age, sex, social class and ethnic identity increase vulnerability to a natural disaster. Ten years after the earthquake in Haiti in 2010, this work deepens the relationship between natural disasters, SV and gender, exploring the unequal distribution of the $\mathrm{SV}$ in the face of a seismic risk. The source of statistical information has been obtained from the Demographic and Health Survey (DHS), developed by the United States Agency for International Development (USAID). Multicriteria decision techniques (TOPSIS) and the differences in differences (DID) technique are used to analyze variations in gender inequality in SV as a result of the catastrophic event. The results obtained reinforce the idea of the negative impact of the disaster on the SV. Additionally, an intensification of the negative effects is observed when the household is headed by a woman, increasing the gap in SV between households headed by women and the rest of the households. The conclusions obtained show additional evidence of the negative effects caused by natural disasters on women, and important implications for disaster risk management are derived that should not be ignored.
\end{abstract}

Keywords: social vulnerability; gender; natural disasters; sustainability; inequality; Haiti

\section{Introduction}

The study of vulnerability constitutes a central axis in the research work on sustainability [1]. The risk combines aspects related to danger, exposure to it and vulnerability [2]. This last aspect refers to those physical, social, economic and environmental factors or processes that increase the susceptibility of a community to the impact of hazards [3]. Adger [4] considers that vulnerability is associated with damage due to exposure to stress due to environmental and social change and the lack of adaptive capacity. The degree of vulnerability of a human group is decisive for a catastrophe to trigger a disaster, hence the opportunity for analysis incorporating its social dimension [5].

In the case of disasters, the reduction of social vulnerability (SV) is a central element of risk management or reduction and has been identified as the most important prerequisite for the resilience of areas prone to disasters [6]. Specifically, SV to hazards plays a fundamental role in the formulation of disaster risk reduction strategies [7]. It analyzes the differences in human capacity to prepare, respond and recover from disasters [8] based on socio-economic, political, institutional, psychological and cultural factors [9]. Its analysis helps to understand humanitarian crises, not as specific, spontaneous 
and inevitable phenomena, but as the result of structural causes and long and medium term processes, many of them modifiable by human action [5]. The results highlight its importance as a starting point to define policies for seismic risk mitigation, emergency management and territorial planning to reduce impacts [6].

Although disasters threaten all the people who suffer from them, they do not affect all members of society equally. Social and economic inequalities make certain groups more vulnerable to disasters. Factors such as age, sex, social class and ethnic identity increase vulnerability to a disaster [10-12]. The World Bank estimates at 520 billion dollars the economic loss in annual consumption as a result of disasters, and almost 26 million people are condemned to poverty every year. An important part of the world's population is vulnerable to disasters [13]. The EU Science Hub [14] estimates that in 2017 one in three people in the world is exposed to earthquakes, around one billion are affected by floods and 414 million live near one of the 220 most dangerous volcanoes.

One of the main determinants of SV is gender [8,15-22]. We understand the gender perspective as an analytical category that allows to identify discrimination based on the characteristics of people, due to their sexual identity and the gender role played. For the specific objectives of this work, without intending to impose restrictive binary categories, nor to exclude sexual minorities [23] this perspective is useful to analyze the differences depending on the person who heads the household, and specifically the differentiated impact when it comes to women or men. In this sense Socio-economic status, educational interruption, workplace, insufficient preventive protection, cultural barriers, marital stress, domestic and sexual violence, persistence of stereotypes, etc. are some of the causes that explain a greater pre-disaster women vulnerability $[15-17,19,20,24,25]$. The lack of coordination between disaster risk reduction agencies coupled with economic and financial problems, which especially impact women, as a consequence of the feminization of poverty, are additional elements to consider. In the post-disaster, aspects such as poor access to drinking water, disruption of transport systems and inaccessibility to health facilities [25] stand out.

According to [2], women and girls around the world have an overwhelming, personal and professional task, with the care of children, housework, the elderly and people with disabilities, and therefore, they are often the last to evacuate the disaster area. So simple life-saving decisions, like deciding when and whether they evacuate, become a difficult choice. They also suffer a greater economic impact after disasters and higher levels of violence. For this reason, numerous investigations incorporate the variable sex as an element of vulnerability $[1,6-8,12,21]$. In the specific case of the 2010 Haiti earthquake, it was found that women are also re-victimized in the post-disaster process [19].

A significant proportion of Latin American and Caribbean area households do not correspond to the image of a nuclear unit of father, mother and children. Specifically, in 2010, according to CEPAL data [26], 30\% of Latin American households were headed by a woman. Although very limited, some studies show how the disaster's vulnerability increases in case of women-headed household $[27,28]$. The work carried out by [28] evaluates the socioeconomic damage of earthquakes in El Salvador in the informal economy of women. It is observed how disasters increase the vulnerability of them and their families through the reduction of their formal and informal work. Furthermore, the fact that women extend their reproductive roles from family to community with unpaid and non-basic decision-making tasks further increases their levels of vulnerability. Bradshaw and Arenas [27] found different sources of vulnerability in families headed by women during and after Hurricane Mitch: a greater dedication to reproductive and community work against the productive, loss the regular source of income, increase the households headed by women and single mothers, violence against women, etc.

Despite the undeniable advances in the study of SV associated with a catastrophe, knowing what the role of social differences within a population is in the impact of a disaster is an unavoidable issue $[8,22]$. In this sense, one of the main limitations identified in the research carried out is the absence or deficient and incomplete incorporation of the gender perspective $[8,21,29]$. The analysis of the specialized literature shows that knowledge of the impact of disasters on the living conditions of 
women is limited. The scientific production on this issue is recent and not very extensive. A good part of the work carried out, of Asian and Anglo-Saxon origin, focuses on the analysis of disasters linked to its territory. This work tries to complement the analysis of the phenomenon in the Latin American and Caribbean area.

After ten years of the 2010 Haiti earthquake, the work deepens the relationship between disasters, social vulnerability and gender, exploring the unequal distribution of social vulnerability to seismic risk. The study analyzes the behavior and characteristics of individual households in Haiti, identifying the differences before and after the disaster, as well as between man -led and women -led households. Taking into account the object of work analysis, the SV will be defined as the set of characteristics of the home and its interaction with the environment that contribute to making it vulnerable to disasters The indicators for assessing social vulnerability caused by disasters are all those characteristics that describe the conditions that contribute to reducing the ability to prepare, respond and recover from hazards [30]. It helps explain the causes that cause some communities to experience a hazard differently from others, even though they are affected by the same magnitude or severity of the hazard in question [31]. Taking into account that they define the capacity of an individual or community to prepare, respond and recover from a particular danger, they can be considered as an effect of social inequalities, given that this capacity is a consequence of the unequal access to opportunities [32,33].

An intrinsic characteristic of social vulnerability is that it constitutes a process product that has an effect of space-temporal scale. Its measurement at different levels (territorial or individual unit) helps to understand its dynamics, from the global to the local or vice versa [34]. In this regard, the SV indicators in territorial terms refer primarily to economic, political factors, infrastructures, medical and support services $[35,36]$. There are numerous studies that show how the economic and political conditions of the country or territory of reference affect their vulnerability to a disaster [37-39]. The works carried out by Peduzzi et. al [40] and Kahn [39] show that developed countries have fewer deaths from disasters than developing countries. The variables most used in the works that analyze the influence of a country's economic factors on its vulnerability are production [gross domestic product (GDP) or regional production], income, employment, inflation, consumption, expenses, savings, financial transfers national and international, public finance and commerce [41-43]. Regarding political factors, Kahn [39] and Raschky [37] find that a country's institutional framework is a key determinant of vulnerability to disasters. Yonson, et al. [43] find for the Philippines a negative association between disaster deaths and socioeconomic development and good governance. In terms of individual SV, sociodemographic characteristics, life situations and financial status are factors to consider [44]. At work, the analysis to be carried out is carried out at the level of the individual considering as fundamental factors that affect the degree of SV aspects related to economic, demographic and housing factors $[6,31,32,45]$.

The work begins by identifying and describing the area of study. A multi-criteria approach based on indicators is used to assess the SV in the event of a catastrophic event through a social vulnerability index [31], order of preference for similarity to the ideal solution (TOPSIS) [46]. This technique constitutes one of the most used classification methods for its logic, simplicity, accessibility and computational efficiency [47,48]. From a set of alternatives valued in a set of decision-making criteria, TOPSIS selects alternatives that simultaneously present the shortest distance from the positive ideal solution (PIS) and the distance farthest from the negative ideal solution (NIS). The positive ideal solution maximizes the criteria of the type "the more, the better" and minimizes the criteria of the type "the less, the better", while the negative ideal solution maximizes the criteria "the less, the better" and minimizes "the more, top".

In a second stage, using an econometric model Differences in Differences (DID), the effect of the impact of the catastrophe on the SV of Haitian households will be estimated. Additionally, one aspect has not been analyzed so far by specialized literature, variations in gender inequality in social vulnerability as a result of a catastrophic event will be addressed. Specifically, it will be studied 
whether the gap between the social vulnerability of women-led households and the rest of households increases, or not, as a result of the earthquake.

The study is part of the analysis of the achievement of the Sustainable Development Goals (SDGs). The 2030 Agenda for Sustainable Development, adopted by all United Nations Member States in 2015 recognizes the close relationship between gender equality and disaster resilience, as well as the importance of this relationship to the achievement of the SDGs. Therefore, it raises the need for studies and analyzes that make gender inequalities and vulnerabilities visible and promote a comprehensive risk reduction among all stakeholders [29].

\section{Study Area}

Haiti is a country located in the western part of the island of Hispaniola, the most mountainous and rugged of the Antilles. It is located in a territory formed by a complex network of tectonic plates and geological faults. From an administrative point of view, it is divided into ten departments, one hundred and forty communes and five hundred and seventy communal sections. The ten departments are: Ouest, Sud, Sud-Est, Grand-Anse, Nippes, Nord, Nord-Ouest, Nord-Est, Center and l'Artibonite. Port-au-Prince is the capital of the country and the center of political and administrative decisions. The urban areas of six municipalities of the Department of the Ouest, including Port-au-Prince, regrouped to form the Metropolitan Area.

On January 12, 2010, a devastating earthquake of magnitude 7.3 on the Richter scale hit the country, causing one of the most serious human catastrophes in history (Figure 1).

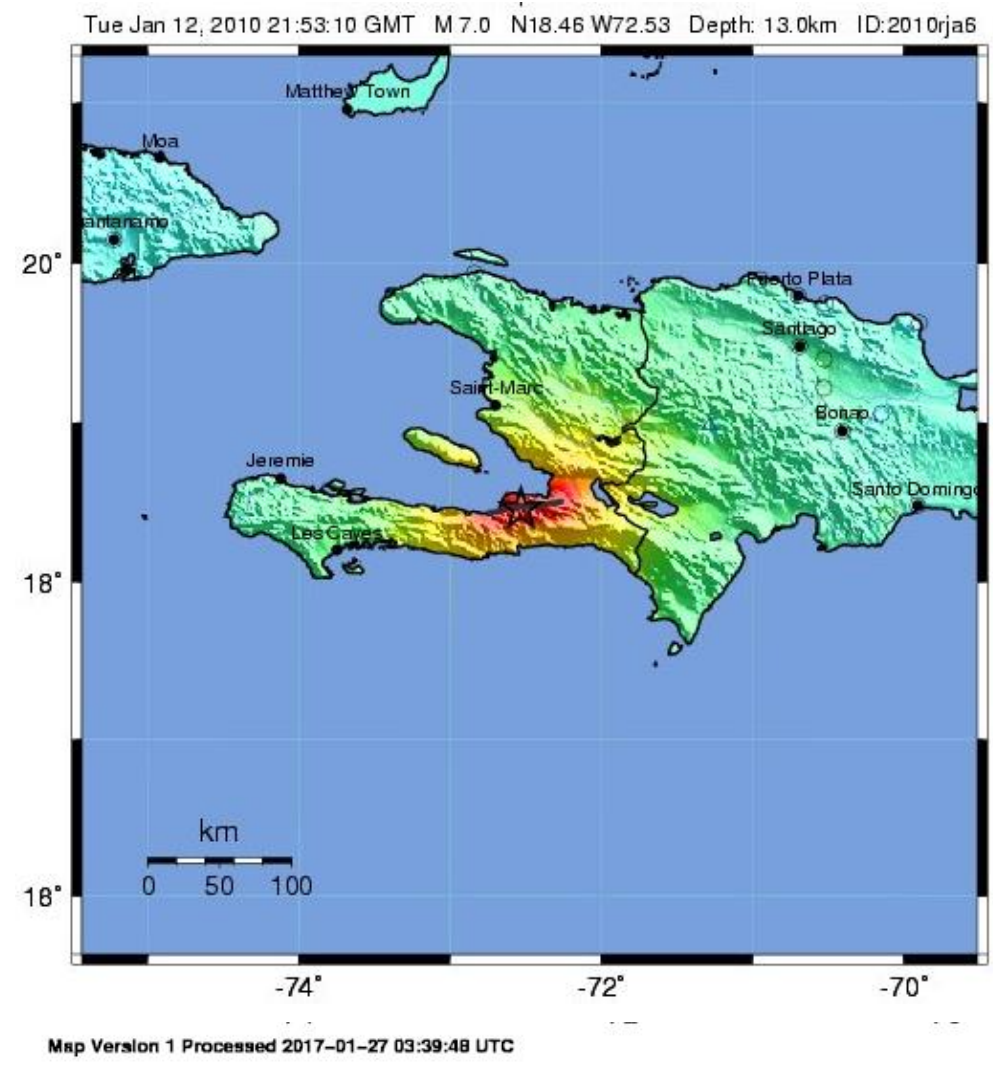

Map Verslon 1 Processed 2017-01-27 03:39:48 UTC

\begin{tabular}{|c|c|c|c|c|c|c|c|c|c|}
\hline $\begin{array}{l}\text { PEACEVED } \\
\text { SHAKING }\end{array}$ & Not felt & Weak & Light & Moderate & Strong & Very strong & Severe & Violent & Extreme \\
\hline $\begin{array}{l}\text { POTENTIAL } \\
\text { DAMAGE }\end{array}$ & none & none & none & Very light & Light & Moderate & Mod/Heavy & Heavy & Very Heavy \\
\hline PEAK ACC. $\left(x_{g} g\right)$ & $<0.05$ & 0.3 & 2.8 & 6.2 & 12 & 22 & 40 & 75 & $>139$ \\
\hline PEAK VEL_. $(\mathrm{cm} / \mathrm{s})$ & $<0.02$ & 0.1 & 1.4 & 4.7 & 9.6 & 20 & 41 & 86 & $>178$ \\
\hline $\begin{array}{l}\text { INSTRUMENTAL } \\
\text { INENSIYY }\end{array}$ & 1 & II-III & IV & V & VI & VII & VIII & IX & $x_{+}$ \\
\hline
\end{tabular}

Figure 1. Intensity of the earthquake in Haiti 2010. Fuente: [49]. 
According to the United States Geological Survey (USGS), its epicenter was located about $25 \mathrm{~km}$ from Port-au-Prince and the hypocenter only $13 \mathrm{~km}$ from the surface, which caused the earth's crash forces to be as intense and destructive as possible [49]. The quake, which mainly affected the city of Port-au-Prince and in the south-west of the country, caused the death of at least 220,000 people, caused more than 300,000 wounded, almost 1.5 million people lost their homes and many others were displaced $[50,51]$. The earthquake severely affected Haiti's infrastructure, more than $65 \%$ of the epicenter buildings, located in the metropolitan area of Port-Prince-Pétionville were completely collapsed or with a high degree of destruction[52]. In a matter of seconds, the disaster ended with 120 percent of the GDP produced by the country in 2009 [53]. A catastrophe of devastating consequences in a country of less than 11 million inhabitants, the poorest in America and one of the poorest in the world.

Currently, Haiti continues to experience the consequences of the earthquake that struck the country in 2010. Considered the poorest territory in America with a Human Development Index (HDI) in 2018 of 0.503 points, a life expectancy of 63.6 years and a National Income Gross per capita of $\$ 1665$ in 2017 [54], constitutes a territory of strong inequalities. If the previous indicators adjusted for inequality are considered, in 2018 the HDI suffers a 40.5\% decline, presents an inequality in life expectancy of $32.2 \%, 37.3 \%$ in education and $50.4 \%$. in the corresponding to the income. With a Gender Inequality Index of 0.620 , Haiti ranks 150th in the ranking of countries ordered from lowest to highest inequality between men and women in 2018, also has a teenage fertility rate of 51.7, a gender differential in percentage of population with at least second grade of education of 13 percentage points in favour of men and an employment gap of 10 percentage points [54].

\section{Materials and Methods}

\subsection{Source of Information}

The Demographic and Health Survey (DHS), prepared by the United States Agency for International Development (USAID) is the source of the statistical information used. The DHS program was established in 1984 and since then surveys have been conducted in 85 countries and in 57 of them at least two surveys in successive waves. Surveys provide detailed and disaggregated data by sex on population, education, employment, health, gender roles and living conditions inside homes. The sample design is done through stratified group sampling in two stages and, in the case of Haiti, it contains representative information at national level and by departments. All the DHS Survey protocols specific to each country are approved by an ethical review board of the host country and the procedures and questionnaires reviewed and authorized, in turn, by an international body (the ICF International Institutional Review Board), according with United States Department of Health and Human Service.

The selected households are visited by a trained interviewer, who conducts the household interview, completes the list of household members and identifies the women and men who respond to the individual interviews. The analysis carried out is based on the information provided by the surveys carried out on women in the 2005-2006 and 2012 waves, which provide data before and after the disaster and, consequently, allow the assessment of the impact. In the first consultation, 2005-2006 survey, a total of 9998 households and 15,715 individuals were interviewed, of which 10,757 were women between 15 and 49 years. In 2012, the total number of interviews amounted to 13,181 households and 23,770 people, of which 14,287 were women between 15 and 49 years old. The final reports of the DHS survey contain information regarding the design of the survey and its technical details $[55,56]$.

At work, only households in which women are either heads of households, or partners or spouses of heads of households are considered. In doing so, a single household survey is available and avoiding the incorporation of interviews conducted with other women in the household, such as grandmothers, sisters, aunts, daughters, visitors, which could distort the sample. Specifically, a total of 
7787 observations, 3373 observations related to the 2006-2006 wave and 4414 observations of the year 2012, respectively, have been considered.

\subsection{Methods}

Work development is done in three stages (Figure 2). First, all available SV indicators in the sample are selected. Second, the SV is quantified in the event of a disaster using the TOPSIS method. Finally, thirdly, by means of a Differences in Differences (DID) estimate, the impact of the 2010 Haiti earthquake on the SV of households is analyzed by assessing whether in women-led households it is increased as a result of the disaster with respect to that of men increased the gender gap in households.

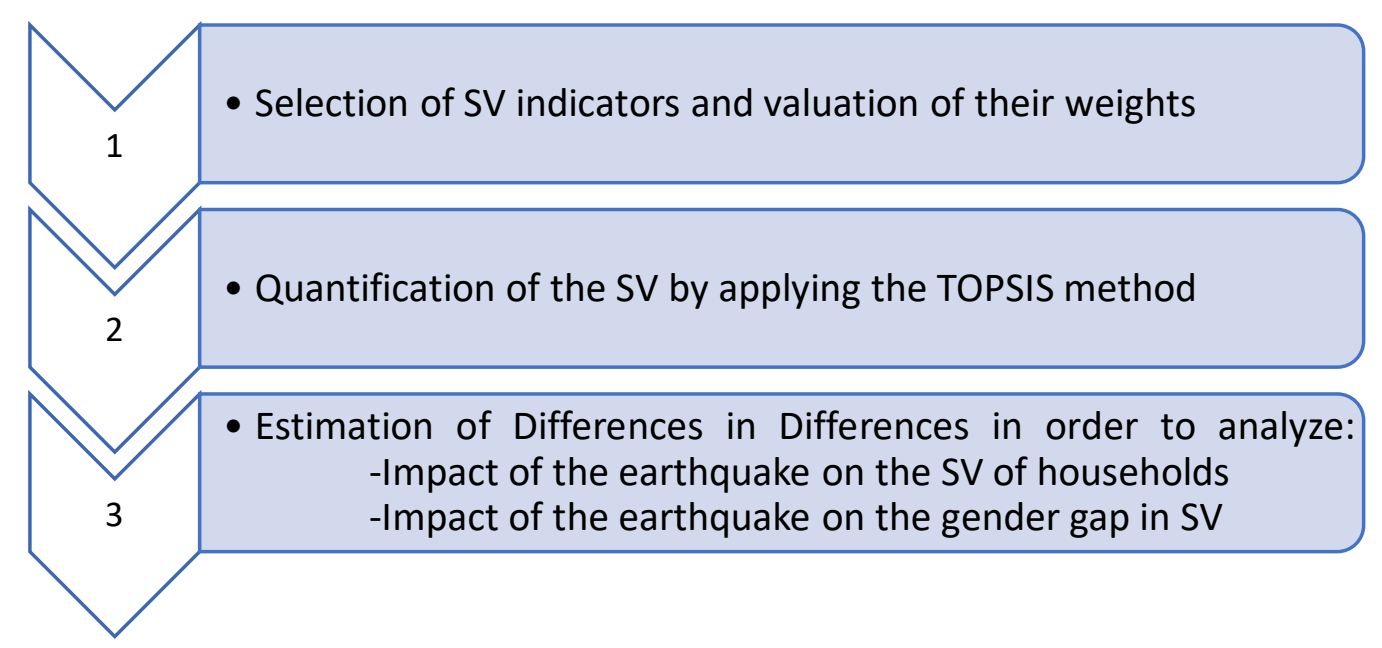

Figure 2. Procedure used in the study. Source: own elaboration.

\subsubsection{Identification of Vulnerability Indicators}

The works developed by Cutter, Boruff and Shirley [32] and Cutter and Morath [31] have been considered for the identification of the characteristics that from the DHS survey and for the territory of Haiti allow the quantification of the SV. A total of 17 variables are considered related to the sociodemographic characteristics of the household, socioeconomic status of the family and housing conditions (Table 1). The variables related to economic factors, medical, school, infrastructure, social networks, community administration and participation, community disaster prevention as well as population groups with 'special needs' have not been incorporated into the analysis because they lack data at the department or district level.

\subsubsection{Technique for Order Preference for Similarity to the Ideal Solution (TOPSIS)}

The quantification of the SV is carried out following different methodological approaches in order to reduce the number of statistically significant variables that describe different aspects of social vulnerability [57,58]. The SV index developed by Cutter et al. [32] for its evaluation in the US, it constitutes one of the first indicators used by principal component analysis (PCA) as a method of developing an indicator. There are numerous studies that subsequently use PCA and factor analysis as data reduction methods [59-63]. Multicriteria analysis techniques (MCDM) are also the methodological support used in countless works. Armas and Gavrin [64] used multicriteria spatial analysis to assess SV in Bucharest (Romania). Martins et al. [65] developed a model based on the geographic information system (GIS) to assess the SV for seismic risk using MCDM through hierarchical structures with three levels of disaggregation. Ouma and Tateishi [66] used techniques of sum of ranges and process of analytical hierarchy (AHP) for the evaluation of the vulnerability index of floods including the social and economic dimensions. Yeol and Chung [67], Chung et al. [68], Yang et al. [1], and Bae et al [69]. 
They used the TOPSIS technique to assess vulnerability in different areas (floods, water resources and health).

Table 1. Social vulnerability indicators and selected variables used in the study.

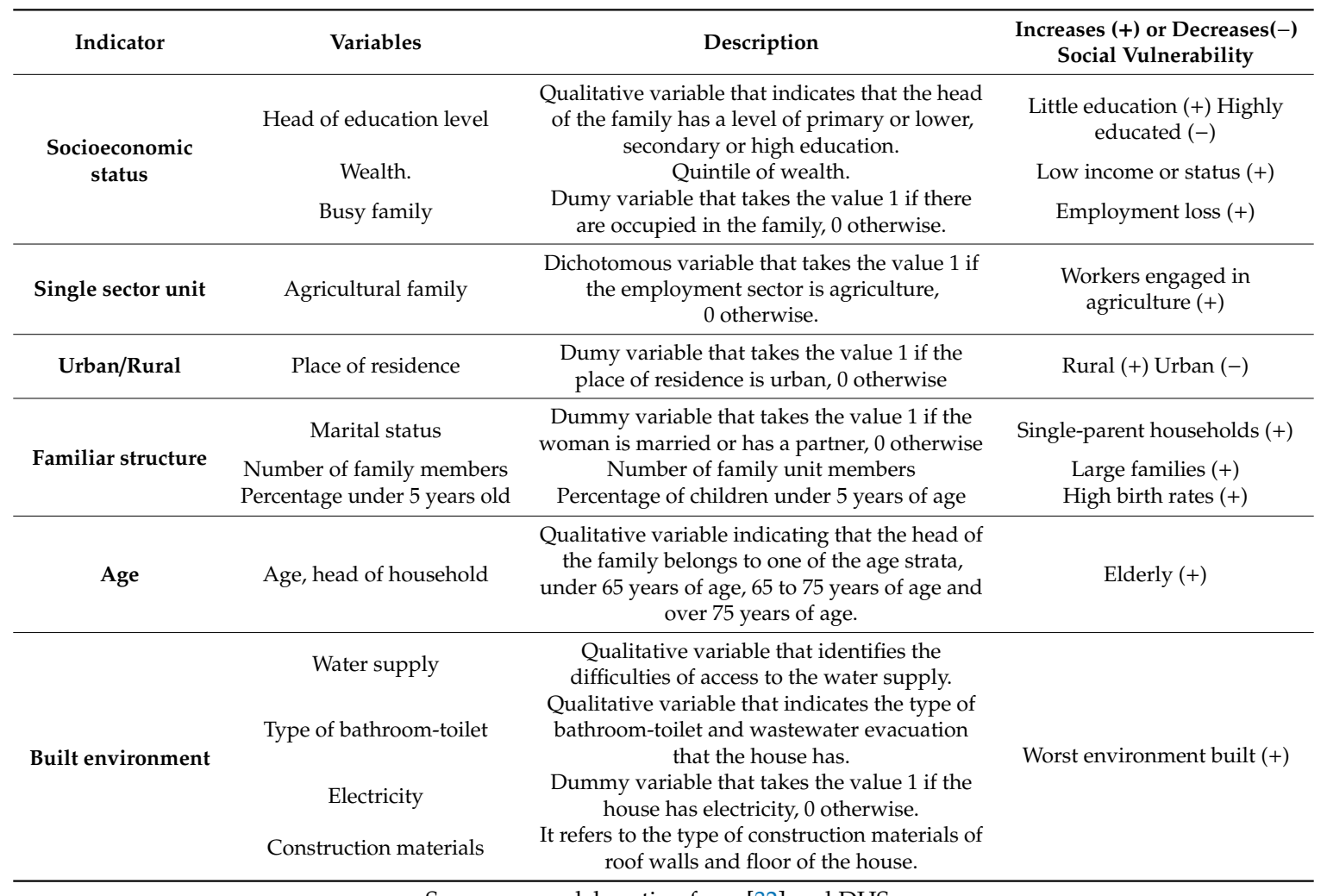

Source: own elaboration from [32] and DHS.

TOPSIS is a simple design technique for vulnerability assessment and important in relation to others [46]. It is suitable when there are multiple attributes and alternatives and especially suitable for use with objective or quantitative data Shih et al. [70]. It has advantages in relation to other alternatives since (1) it allows to obtain a compromise efficiently; (2) represents the rationality of human choice; (3) express the best and worst alternatives simultaneously; (4) uses an easily programmable understandable calculation process; (5) performance measures of all alternatives in the attributes can be visualized in a polyhedron, at least for two dimensions; (6) and allows explicit compensation and interactions between attributes $[1,47,48,71-73]$. However, few reports have used it for the assessment of the SV to natural hazards and generate decision support alternatives [74]. Based on the advantages and features that define it in this work, TOPSIS will be used, under a classical approach, MCDM classification method. TOPSIS selects decision alternatives that simultaneously have the shortest distance from the positive ideal solution (PIS) and the farther distance from the negative-ideal solution (NIS). The positive ideal solution maximizes criteria of the type "the more, the better" and minimizes criteria of the type "the less, the better", whereas the negative ideal solution maximizes "the less, the better" criteria and minimizes "the more, the better" criteria. The main steps of a classical TOPSIS approach can be summarized as follows:

Sтер 1. Determine the decision matrix $X$, where the number of alternatives is $m$ and the number of criteria is $n, X=\left(x_{i j}\right)_{m \times n^{\prime}}$, being $x_{i j}$ real numbers.

STEP 2. The elements of the decision matrix may not be determined in the same domain and therefore must be standardized. Construct the normalized decision matrix:

$$
R=\left(r_{i j}\right)_{m \times n}
$$


Being:

$$
r_{i j}=\frac{x_{i j}}{\sum_{1}^{m}\left(x_{i j}\right)^{2}} i=1,2,3 \quad j=1,2,3,4
$$

STEP 3. Determine the weighted normalized decision matrix. Given, $w_{j} \in[0,1]$ with $\sum w_{j}=1$, we calculate:

$$
v_{i j}=w_{j} r_{i j}, i=1, \ldots, m, \quad j=1, \ldots, n .
$$

SтEP 4. Determine the positive ideal $A^{+}$(PIS) and negative ideal $A^{-}$solutions (NIS),

$$
\begin{aligned}
& A^{+}=\left\{v_{1}^{+}, \ldots, v_{n}^{+}\right\}=\left\{\left(\max _{i} v_{i j}, j \in F^{+}\right)\left(\min _{i} v_{i j}, j \in F^{-}\right)\right\} \quad i=1,2, \ldots, m \\
& A^{-}=\left\{v_{1}^{-}, \ldots, v_{n}^{-}\right\}=\left\{\left(\min _{i} v_{i j}, j \in F^{+}\right)\left(\max _{i} v_{i j}, j \in F^{-}\right)\right\} \quad i=1,2, \ldots, m
\end{aligned}
$$

where $F^{+}$is associated with "the more, the better" criteria and $F^{-}$is associated with "the less, the better" criteria.

STEP 5. Calculate the separation measures with respect to the PIS and NIS:

$$
\begin{gathered}
S_{i}^{+}=\left(\sum_{j=1}^{n}\left(v_{i j}-v_{j}^{+}\right)^{2}\right)^{1 / 2}, \\
S_{i}^{-}=\left(\sum_{j=1}^{n}\left(v_{i j}-v_{j}^{-}\right)^{2}\right)^{1 / 2}, \\
1 \leq i \leq m .
\end{gathered}
$$

STEP 6. Calculation of the relative proximity of each alternative to the ideal solution

$$
R_{i}=\frac{S_{i}^{-}}{S_{i}^{+}+S_{i}^{-}}, 1 \leq i \leq m .
$$

where $R_{i}$ takes values between 0 and 1 and the $i$-th alternative is closer to the ideal solution if the value of $R_{i}$ is closer to one.

In the context that concerns us, and given that the value 1 is associated with the ideal situation, minimum vulnerability, and the value 0 with maximum vulnerability, $R_{i}$ will constitute an indicator of household social vulnerability.

\subsubsection{Differences in Differences Technique (DID)}

To measure the impact of the earthquake on gender relations, the quasi-experimental differences in differences (DID) technique is used, which uses longitudinal data from two population groups, treatment and control, to obtain an appropriate counterfactual that allows the estimation of a causal effect (Figure 3). In our study, the temporal variable ( $t$ ) includes the pre-disaster points (wave of the 2005-6 survey, $t=0$ ), and the post-disaster (wave of the 2012 survey, $t=1$ ) thus allowing the comparison of households affected by the earthquake and those not affected in the aforementioned temporary references. In our case, the DID estimator would represent the difference between what happened before and after the 2010 earthquake in Haiti between the group affected by the disaster and the control group $[75,76]$. 


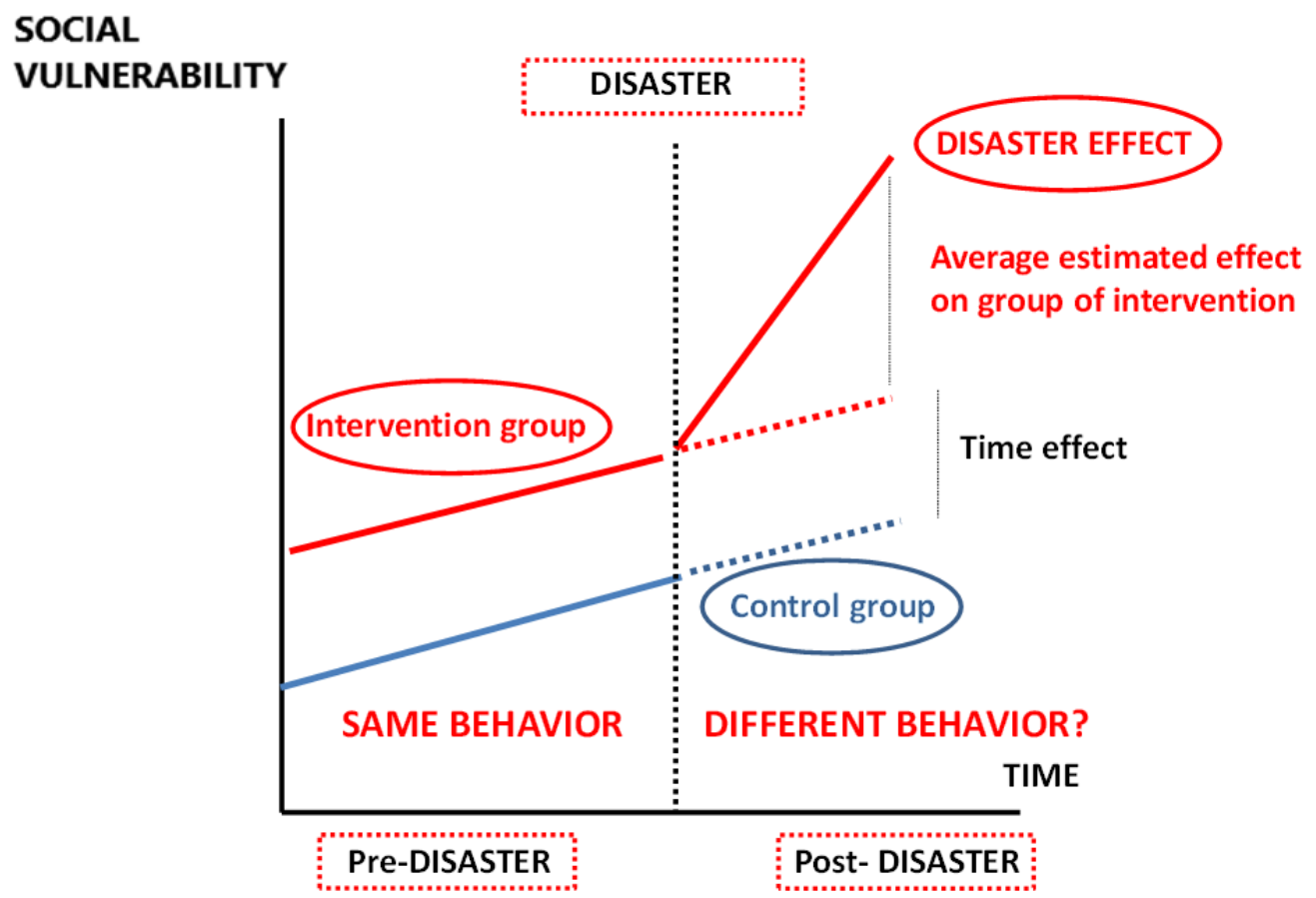

Figure 3. Differences in differences estimator (DID). Source: graphic created by the authors based on [22].

Following the work done by Weitzman and Behrman in the analysis of the impact of the disaster in Haiti on the sexual violence of women [77], the application of the DID methodology is carried out by combining the information obtained from DHS survey (waves 2005-06 and 2012) with the intensity of the earthquake to capture how it affects the SV of Haitian households and whether women-led households increase their vulnerability gap with respect to men-led households as a result of the disaster. From a temporary variable, the observations related to the 2005-6 wave constitute those not exposed to the disaster $(t=0)$, while those corresponding to 2012 are those related to post-disaster $(t=1)$.

The intensity of the earthquake is measured from the averages by department of the Mercalli scale, calculated by Weitzman and Behrman, who assign the 2012 DHS survey groups by plotting geocoded groups to the earthquake intensity map provided by US Geological Survey [49] (Table 2). The Mercalli scale is an internationally recognized scale that allows the intensity of earthquakes to be assessed through their effects or damage to different structures [78]. It takes values between 1 (imperceptible earthquake) and 12 (total destruction with few survivors) considering a strong earthquake when the average score is equal to or greater than 5. By department for the 2010 earthquake in Haiti the average scores range from 4.7 in Nord (moderate) and 7.97 in Ouest (very strong) to be included in three categories: "Moderate disaster", departments with an average Mercalli score of less than 5; "Strong disaster" $\left(D_{1}=1\right)$ departments with an average Mercalli score greater than 5 and less than 7 ; and "Very strong disaster" $\left(D_{2}=1\right)$ departments with an average score greater than 7 (Table 2). In this way, the control group will be made up of families residing in the departments with an average score on the Mercalli scale of less than 5 , "Moderate disaster" $\left(D_{1}=D_{2}=0\right)$. The treatment group will be formed by residents in the departments with "Strong Disaster" $\left(D_{1}=1\right)$ or "Very Strong Disaster" $\left(D_{2}=1\right)$.

In the econometric specification of the DID model the dependent variable SV denotes social vulnerability; $\mathrm{SH}$, independent variable, the "Sex of the head of the family", a dichotomous variable with a value of 1 if the head of the family is man and 0 otherwise, and, the random disturbance term. Based on the effect on the factor-dependent variable and its interaction with the other variables in 
the model, the work estimates the impact of the disaster and its intensity on social vulnerability and gender (gender) inequality:

$$
\begin{gathered}
S V_{i}=\beta_{0}+\beta_{1} D_{1 i}+\beta_{2} D_{2 i}+\beta_{3} S H_{i}+\beta_{4} t_{i}+\beta_{5}\left(D_{1 i} \times t_{i}\right)+ \\
+\beta_{6}\left(D_{2 i} \times t_{i}\right)+\beta_{7}\left(S H_{i} \times t_{i}\right)+u_{i}
\end{gathered}
$$

The DID estimate is based on the interaction terms established between the variables of the model. These terms include the estimated differential effect with respect to the so-called base or control category, that is, surveyed households that live in areas of Haiti that were only moderately affected by the earthquake and are led by women.

Table 2. Average score of Mercalli Haiti earthquake 2010 by department.

\begin{tabular}{ccc}
\hline Región & Average Mercalli Score & Typical Deviation \\
\hline Nord & 4.70 & 0.55 \\
Grand'anse & 4.71 & 0.14 \\
Nord-Est & 4.79 & 0.05 \\
Nord-Ouest & 4.80 & 0.30 \\
Artibonite & 5.17 & 0.33 \\
Sud & 5.32 & 0.66 \\
Centre & 5.33 & 0.33 \\
Nippes & 5.60 & 2.26 \\
Sud-Est & 6.44 & 1.86 \\
Ouest & 7.97 & 1.42 \\
\hline
\end{tabular}

\section{Results}

From the variables collected in Table 1 and from the information provided by the SHS survey, we selected 15 variables for the preparation of the SV index from a sample of 7787 observations. The corresponding descriptive statistics are shown in Table 3. For the qualitative variables information is displayed on the number of observations that satisfy the analyzed characteristic and its relative frequency. For the mean quantitative variables and the sample standard deviation are the indicators considered.

Regarding sociodemographic characteristics, in the Haitian context, there are several issues to consider. In all regions and for the two waves of the survey, a high percentage of the population has a very low educational level. Of the total sample, more than 70 percent declare an educational level of primary or lower school and only $2907 \%$ of households are led by individuals with a higher educational level in 2005-06, a figure significantly increased in 2012 until the 6.05\% The high number of family members, with an average of more than 5 people per family unit in both temporary references and an average percentage of children under 5 years of age close to $20 \%$, is a remarkable fact.

Socio-economic status is visible through indicators of education, occupation and wealth quintile. Regarding the occupation, although in the context of Haiti during the period considered the unemployment rate is $70 \%$, the interviewees declare a very high average occupation close to $90 \%$. Using a variable that identifies those families that declare someone busy seems, therefore, a more appropriate option. The Occupied variable will take the value 1 for the sample units with some occupied and the value 0 otherwise. The variable Agricultural sector identifies the families in which some of its member's work in the agricultural sector. This variable has a frequency higher than $50 \%$ in the 2005-06 wave, decreasing 5 percentage points in the 2012 survey. Finally, the Wealth variable includes the wealth quintile in which the interviewed family is located, understanding as such an indicator prepared by DHS (2019) that constitutes a composite measure of the cumulative standard of living of household wealth. 
Table 3. Social vulnerability indicators and variables used in the study. Descriptive statistics of the sample.

\begin{tabular}{|c|c|c|c|c|c|c|}
\hline \multirow{2}{*}{ Dimensions } & \multirow{2}{*}{ Variables } & \multirow{2}{*}{ Categories } & \multicolumn{2}{|c|}{ 2005-2006 } & \multicolumn{2}{|c|}{2012} \\
\hline & & & Number of Cases & Frequency & Number of Cases & Frequency \\
\hline \multirow{12}{*}{ Sociodemographic characteristics } & \multirow{2}{*}{ Marital status } & Not in acouple & 291 & 8.63 & 390 & 8.84 \\
\hline & & In a couple & 3082 & 91.37 & 4021 & 91.16 \\
\hline & \multirow{2}{*}{ Place of residence } & Rural & 1981 & 58.73 & 2672 & 60.53 \\
\hline & & Urban & 1392 & 41.27 & 1742 & 39.47 \\
\hline & \multirow{3}{*}{ Age head of household } & Under 65 & 3328 & 98.67 & 4351 & 98.57 \\
\hline & & Between 65 and 75 years old & 21 & 0.62 & 42 & 0.95 \\
\hline & & Over 75 years old & 24 & 0.71 & 21 & 0.48 \\
\hline & \multicolumn{2}{|c|}{ Continuous variables } & Mean & Std. Dev. & Mean & Std. Dev. \\
\hline & \multicolumn{2}{|c|}{ Number of family members } & 5.4455 & 2.2752 & 5.2251 & 2.2280 \\
\hline & \multicolumn{2}{|c|}{ Percentage under 5 years old } & 18.4213 & 16.8150 & 17.1600 & 16.8150 \\
\hline & \multirow{2}{*}{ Variables } & \multirow{2}{*}{ Categories } & 2005-2006 & 2012 & 2005-2006 & 2012 \\
\hline & & & Number of Cases & Frequency & Number of Cases & Frequency \\
\hline \multirow{13}{*}{ Socioeconomic status } & \multirow{4}{*}{ Family head of education level } & No education & 1115 & 33.06 & 1014 & 22.97 \\
\hline & & Primary & 1327 & 39.34 & 1760 & 39.64 \\
\hline & & High school & 834 & 24.73 & 1372 & 31.08 \\
\hline & & High & 97 & 2.88 & 268 & 6.07 \\
\hline & \multirow{2}{*}{ Busy family } & Busy & 3287 & 97.45 & 4291 & 97.21 \\
\hline & & Not busy & 86 & 2.55 & 123 & 2.79 \\
\hline & \multirow{2}{*}{ Agricultural family } & Agricultural sector & 1816 & 53.84 & 2148 & 48.66 \\
\hline & & No agricultural sector & 1557 & 46.16 & 2266 & 51.34 \\
\hline & \multirow{5}{*}{ Wealth } & Very poor & 789 & 23.39 & 1047 & 23.70 \\
\hline & & Poor & 634 & 18.80 & 869 & 19.69 \\
\hline & & Medium & 715 & 21.20 & 865 & 19.60 \\
\hline & & Rich & 723 & 21.43 & 918 & 20.80 \\
\hline & & Very rich & 512 & 15.18 & 716 & 16.22 \\
\hline
\end{tabular}


Table 3. Cont

\begin{tabular}{|c|c|c|c|c|c|c|c|}
\hline & \multirow{2}{*}{ Variables } & \multirow{2}{*}{\multicolumn{2}{|c|}{ Categories }} & 2005-2006 & 2012 & 2005-2006 & 2012 \\
\hline & & & & Number of Cases & Frequency & Number of Cases & Frequency \\
\hline & \multirow{2}{*}{ Water supply } & \multicolumn{2}{|c|}{ External supply or natural resources } & 1947 & 57.72 & 3130 & 70.91 \\
\hline & & \multicolumn{2}{|c|}{ Running water outside of the house } & 1353 & 40.11 & 1245 & 28.21 \\
\hline & \multirow{4}{*}{ Type of bathroom-toilet } & \multicolumn{2}{|c|}{ Running water in housing } & 73 & 2.16 & 39 & 0.88 \\
\hline & & \multicolumn{2}{|r|}{ In situ } & 194 & 5.75 & 360 & 8.16 \\
\hline & & \multicolumn{2}{|r|}{ Pit latrine } & 2754 & 81.65 & 4001 & 90.62 \\
\hline & & \multicolumn{2}{|r|}{ Conventional } & 425 & 12.60 & 54 & 1.22 \\
\hline & \multirow{2}{*}{ Electricity } & & Does not have & 2429 & 72.01 & 2981 & 67.54 \\
\hline & & & Has & 944 & 27.99 & 1433 & 32.46 \\
\hline \multirow{9}{*}{ Built environment } & \multirow{9}{*}{ Construction materials } & \multirow{3}{*}{ Floor } & Land/manure & 1421 & 42.13 & 1858 & 42.09 \\
\hline & & & Wood/palm/bamboo & 14 & 0.42 & 10 & 0.23 \\
\hline & & & Cement/ceramic-parquet & 1938 & 57.46 & 2546 & 57.68 \\
\hline & & \multirow{3}{*}{ Walls } & Without partitions, cane/palm & 671 & 19.89 & 673 & 15.25 \\
\hline & & & Cane/palm/logs/stone with mud & 563 & 16.69 & 817 & 18.51 \\
\hline & & & Conventional & 2139 & 63.42 & 2924 & 66.24 \\
\hline & & \multirow{3}{*}{ Ceiling } & Roofless/straw & 432 & 12.81 & 423 & 9.58 \\
\hline & & & Bamboo mat/wood planks & 38 & 1.13 & 222 & 5.03 \\
\hline & & & Metal/Cement Fiber & 2903 & 86.07 & 3769 & 85.39 \\
\hline
\end{tabular}

Source: Our elaboration, based on the DHS. 
The indicators of the built environment are related to the availability of electricity, bathroom and running water inside the house, as well as the quality of the materials used in its construction. Haiti is one of the poorest countries in the world and many households lack the basic living conditions. The available statistical information shows that in the 2005-06 wave, 57.72\% of the households interviewed have a natural or external source of water supply, only $12.6 \%$ of a conventional bathroom-toilet inside the house and 72.01\% lack of electricity. The information available in 2012 does not derive a substantial improvement in Haitian habitability conditions, $67.54 \%$ still lack electricity, $70.91 \%$ water in the home and only 1.22 has a conventional bathroom-toilet inside the living place. Homes built with materials such as wood, palm or bamboo are also very frequent.

The evaluation of social vulnerability in the context of Haitian households is carried out using the TOPSIS method. From studies conducted, the directional direction of the factors is identified taking into account their influence on the SV $[6,32,45]$. The positive and negative directionality is attributed to factors that decrease or increase, respectively, vulnerability. The determination of the weight of each criterion or indicator shows its comparative importance in the SV. The approaches used to obtain the differential weights of the indicators are diverse [79]. However, assigning weights equal to all criteria is the most widely used approach $[25,68,69]$ As a working hypothesis, each indicator will be considered to contribute similarly to the social vulnerability of the household. As a final objective, the work aims to analyze the variability in the SV of the home and, ultimately, contribute to understanding its complexity. In the absence of a defensible method of assigning weights, the equal weights option is best $[31,80]$.

The quartile division of the scores obtained allows, using the Stata program, the visual comparison of the SV from a spatial perspective (Figure 4). The legend in Figure 4 shows the intervals of the distribution made. The relationship between the distribution of the SV and its deviations from the mean is represented in circles. The hollow and filled circles collect the lower and upper deviations, respectively, at the mean of the SV. The larger the circle, the further the value of the region will be from the average of Haiti. In both waves of the survey the circles that identify high values of SV are located in the urban area of Haiti. The Center and Nort-Ouest regions or departments constitute the most vulnerable areas of Haiti in the wave of the 2005-2006 survey with a minimum score of 0.8038 and an average indicator of 0.851396. Sud, Nippes, Sud-Est and Artibonite are the least spatially vulnerable regions with scores ranging between 0.803696 and 0.856845 . The rest of the regions of Haiti, which includes the Ouest region where the capital, Port-au-Prince, is located, have average SV levels with scores ranging from 0.850841 to 0.8518284 . During the analyzed time period the dispersion of the SV scores is very low, with an average score of 0.851827 and a standard deviation of 0.0053223 is the region with the highest dispersion.

In general terms the average score of the SV decreases by $18.83 \%$ between the two waves of the survey, 0.85169316 in 2005-06 compared to 0.69125032 in the wave of 2012. The displacement of the SV to regions where the intensity of the earthquake is higher it is evidenced in Figure 4. The Ouest region where the tremor affected most intensely becomes one of the most vulnerable regions with an average score of 0.6962173 and values ranging between 0.4974352 and 0.8566667 . In a similar situation is the Nippes region that significantly increases its SV level and also highlights the Center region with an average score that decreases by $19.8 \%$. With respect to the number of regions in each quartile, it is evident from the results that the number of regions with high, medium high, medium low and low vulnerability was 2, 4, 4, and 0 in the 2005-06 wave versus 4, 3, 2 and 1 in the 2012 survey, taking into account that in each of the waves the distribution in quartiles was carried out based on the data of that time reference. Finally, if we group the departments into the treatment and control groups, we can visualize the effect of the earthquake on the mean value of SV. In the 2005-2006 wave, the mean SV for the control group was 0.85137026 , similar to that for the treatment group, 0.85184319 . However, after the 2010 disaster the differences between the two groups are evident. For 2012, the mean SV in the control group is 0.70728437 , while the mean for the treatment group is 0.68313921 (Table 4). 


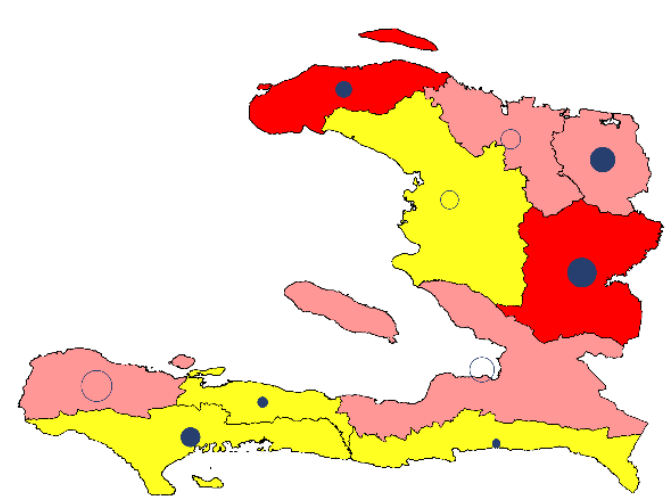

$(0.856386,0.856845)$

$(0.851671,0.856386)$

$\square(0.846957,0.851671)$

$(0.803695,0.846957)$

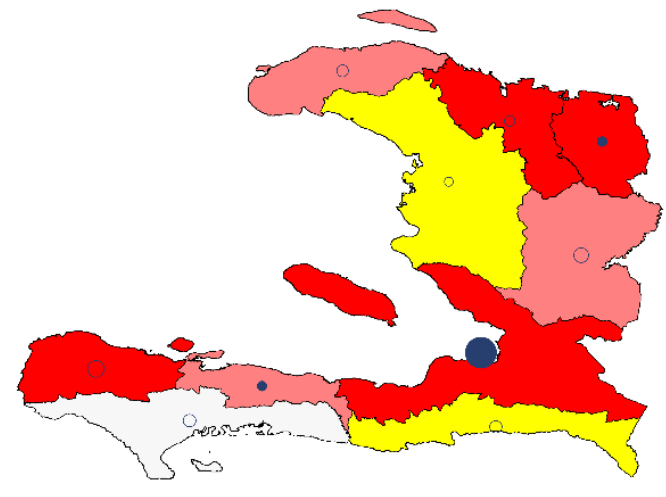

(0 853717, 0.85499)

$(0.852641,0.85371)$

$(0.850507,0.85192)$

$(0.83017,0.850507)$

(a)

(b)

Figure 4. Social vulnerability map. Haiti. Social Vulnerability Haiti 2005-2006 (a) Social Vulnerability Haiti 2012 (b). Source: Our elaboration, based on the DHS. Fix legend number alignment

Table 4. Descriptive statistics of SV indicators for treatment and control groups.

\begin{tabular}{ccccc}
\hline \multirow{2}{*}{ Descriptive Statistics } & \multicolumn{2}{c}{ Control Group } & \multicolumn{2}{c}{ Tratament Group } \\
\cline { 2 - 5 } & $\mathbf{2 0 0 5 - 2 0 0 6}$ & $\mathbf{2 0 1 2}$ & $\mathbf{2 0 0 5 - 2 0 0 6}$ & $\mathbf{2 0 1 2}$ \\
\hline Mean & 0.85137 & 0.69369 & 0.85184 & 0.68318 \\
Median & 0.85232 & 0.84800 & 0.85264 & 0.84773 \\
Maximum & 0.85684 & 1.00000 & 0.85684 & 0.85683 \\
Minimum & 0.81052 & 0.49670 & 0.80370 & 0.47612 \\
Std. Dev. & 0.00487 & 0.17626 & 0.00462 & 0.17523 \\
\hline Observations & 1224 & 1418 & 2149 & 2995 \\
\hline
\end{tabular}

Source: Our elaboration, based on the DHS.

Once the scores of the SV have been obtained and compared, the results obtained from the DID estimate made in order to study the impact of the earthquake on the SV and gender relations are analyzed below through to differences between women- headed household and men-headed household, taking into account that gender stereotypes traditionally attribute this role to men.

Table 5 shows the results obtained from the weighted estimate with the survey weights provided by DHS. From the results obtained, we can estimate how the earthquake that occurred in 2010 affected social vulnerability in the context of Haitian households, in addition to analyzing gender relations within the household. The goal is to find out if women-headed households have worsened or improved their SV after the disaster. The estimators are statistically significant and the contrasts of global significance, from the Wald Chi-square test (2260.430) and the F-Snedecor test, (322.9186) indicate that the model is globally significant for a 99.99 percent confidence level. The collinearity indicators do not show severe problems of linear association between the explanatory variables of the model, with the exception of the variable, $D_{2}$ and SH that have a VIF greater than 10 and eigenvalues close to 0 . The Breusch-Pagan-Goddfrey contrast visualizes the presence of heterocedasticity in the model $(F$-statistic $=3.27 .0230 ; p$-value $=0.00001)$ and therefore we decided to consider standard errors and robust covariances. 
Table 5. Estimation of the effect of the 2010 Haiti disaster on Social Vulnerability. Model Differences in Differences considering earthquake intensity zones.

\begin{tabular}{ccccc}
\hline \multicolumn{5}{c}{ Dependent Variable: $S V$ (Social Vulnerability) } \\
\hline Variable & Coefficient & Std. Error & t-Statistic & Prob. \\
\hline$C$ & 0.851524 & 0.005524 & 154.1580 & 0.0000 \\
$D_{1}$ & 0.000849 & 0.004252 & 0.199690 & 0.8417 \\
$D_{2}$ & -0.000491 & 0.011331 & -0.043289 & 0.9655 \\
$S H$ & 0.000413 & 0.005374 & 0.076835 & 0.9388 \\
$t$ & -0.199860 & 0.007425 & -26.91671 & 0.0000 \\
$D_{1} \times t$ & 0.030653 & 0.006800 & 4.508103 & 0.0000 \\
$D_{2} \times t$ & 0.118791 & 0.012086 & 9.829164 & 0.0000 \\
$S H \times t$ & 0.036803 & 0.006723 & 5.474370 & 0.0000 \\
\hline R-squared & 0.225155 & Mean dependent var & 0.540902 \\
Adjusted R-squared & 0.224458 & S.D. dependent var & 0.596215 \\
S.E. of regression & 0.115175 & Akaike info criterion & -1.483702 \\
Sum squared resid & 103.1905 & Schwarz criterion & -1.476551 \\
Log likelihood & 5784.794 & Hannan-Quinn criter. & -1.481251 \\
F-statistic & 322.9186 & Durbin-Watson stat & 0.213074 \\
Prob(F-statistic) & 0.000000 & Weighted mean dep. & 0.794292 \\
\hline
\end{tabular}

Method: Ordinary Minimum Squares. Weights provided by the DHS survey were used. Huber-White-Hinkley (HC1) heteroskedasticity consistent standard error and covariance. Sample sizes: Moderate disaster zone (N2005 = 1224, N2012 = 1419) Strong disaster zone (N2005 = 1877, N2012 = 2677); Very strong disaster zone (N2005 = 272, N2012 $=318$ ). Total observations included: 7787. Source: Our elaboration, based on the DHS.

The fixed effects of the territory on the social vulnerability of Haitian households are collected through the variables $D_{1}(0.000849)$ and $D_{2}(-000491)$ whose effect on the SV of families is not statistically significant and, $(p$-value $=0.9655)$ and $(p$-value $=0.8417)$, respectively. The fixed effect on inequality in the social vulnerability of households by reason of sex is collected through the variable, its effect being expressed in the model as superior for men in relation to women (0.000413) but not statistically significant $(p$-value $=0.9388)$ as a result of collinearity noted.

The fixed effects related to the 2012 period are those included in the parameter that accompanies the temporal variable $t$ and are shown as negative $(-0.199860)$ and statistically significant $(p$-value $=0.00001)$ for the year 2012 indicating a fixed post-earthquake negative differential effect in the vulnerability of families.

Through the term of interaction with the variable "head of the family" and de temporal variable $t$, $S H \times t$, it is observed that the negative effects of disaster when the household is headed by a woman, increasing the gap between the social vulnerability of households headed by women and the rest of households. The coefficient accompanying the variable $S H \times t$ reflects the differential effect between the pre and post-earthquake states of the fixed effects on the family's SV due to sex of the head of the family. The sign is displayed as positive $(0.036803)$ and statistically significant $(p$-value $=0.0000)$. A positive interaction suggests that the SV of the women-led family's increases in relation to the masculine ones when the disaster occurs, while a negative interaction would suggest otherwise. In summary, according to the estimation made by the 2010 Haiti earthquake, the SV of women-headed households increased in relation to men-headed households. This highlights the negative impact of gender stereotypes on women, based on the provider role that is traditionally assigned to men, putting women at a disadvantage when they have that role.

The estimate shows how the disaster has positive effects of increasing territory with the intensity of the earthquake and statistically significant on the SV of families, regardless of the sex of the head of the family. The multiplicative effect of earthquake exposure based on its intensity is captured by the term of interaction between the variables that define the territory, $D_{1}$ and $D_{2}$, and the temporal variable $t$. For respondents living in areas with a very strong earthquake intensity, the DID estimator sign is positive $(0.118791)$ and statistically significant $(p$-value $=0.0000)$. A similar result is obtained for 
families residing in areas where the intensity of the earthquake was strong, $D_{2}$,with an estimator of differences in positive $(0.030653)$ and statistically significant $(p$-value $=0.0000)$ differences. This result indicates a reduction in the social vulnerability associated with the territory in the face of a catastrophic effect to a greater extent the greater the intensity of the territory.

When the average intensity of the disaster by department, $I$, is used as an indicator of the magnitude of the disaster, based on the model:

$$
S V_{i}=\beta_{0}+\beta_{1} I_{i}+\beta_{2} S H_{i}+\beta_{3} t_{i}+\beta_{4}\left(I_{i} \times t_{i}\right)+\beta_{5}\left(S H_{i} \times t_{i}\right)+u_{i}
$$

Similar results are obtained (Table 6). The effect of the earthquake intensity on social vulnerability is collected from the variables $I$ and $I \times t$. It indicates that as the average intensity of the earthquake increases, the SV of households decreases. The estimation of the coefficient associated with the multiplicative term is positive $(0.037289)$ and statistically significant $(p$-value $=0.0000)$.

Table 6. Estimation of the effect of the 2010 Haiti disaster on Social Vulnerability. Model Differences in Differences considering the average intensity of the earthquake by Department.

\begin{tabular}{ccccc}
\hline \multicolumn{5}{c}{ Dependent Variable: $S V$ (Social Vulnerability) } \\
\hline Variable & Coefficient & Std. Error & t-Statistic & Prob. \\
\hline$C$ & 0.851534 & 0.016511 & 51.57318 & 0.0000 \\
$I$ & $8.27 \times 10^{-05}$ & 0.002905 & 0.028465 & 0.9773 \\
SH & 0.000412 & 0.005364 & 0.076793 & 0.9388 \\
$I \times t$ & -0.379539 & 0.019047 & -19.92657 & 0.0000 \\
$S H \times t$ & 0.037289 & 0.003146 & 11.85173 & 0.0000 \\
R-squared & 0.036848 & 0.006708 & 5.493126 & 0.0000 \\
Adjusted R-squared & 0.227563 & Mean dependent var & 0.540902 \\
S.E. of regression & 0.227066 & S.D. dependent var & 0.596215 \\
Sum squared resid & 0.114981 & Akaike info criterion & -1.487328 \\
Log likelihood & 102.8699 & Schwarz criterion & -1.481965 \\
F-statistic & 5796.911 & Hannan-Quinn criter. & -1.485490 \\
Prob(F-statistic) & 458.4622 & Durbin-Watson stat & 0.215105 \\
& 0.000000 & Weighted mean dep. & 0.794292 \\
\hline
\end{tabular}

Method: Ordinary Minimum Squares. Weights provided by the DHS survey were used. Huber-White-Hinkley (HC1) heteroskedasticity consistent standard error and covariance. Moderate disaster zone $(\mathrm{N} 2005=1224, \mathrm{~N} 2012=1419)$ Strong disaster zone $(\mathrm{N} 2005=1877$, N2012 = 2677); Very strong disaster zone $(\mathrm{N} 2005=272$, N2012 = 318). Total observations included: 7787. Source: Our elaboration, based on the DHS.

\section{Conclusions}

Natural hazards constitute a serious obstacle to human development and the fulfillment of the Sustainable Development Goals. They are the result of the interaction between human beings and Nature and their risks are highly influenced, both positively and negatively, by the development process. Negative impacts are perceived with greater intensity in poor countries and cause considerable material and human losses [6,81]. They destroy infrastructure and destroy the livelihoods of millions of people, especially those who are the poorest and most vulnerable. In the case of natural disasters, social vulnerability plays a fundamental role in the formulation of risk reduction, emergency management and territorial planning strategies to reduce their impacts and their study constitutes one of the central issues in sustainability research. The SV is related to the demographic characteristics, the socioeconomic status and the characteristics of the built environment, as well as to all those elements related to institutional, political and cultural aspects that may affect the response capacity of individuals to cope, recover and adapt to catastrophic events.

This work constitutes an attempt to contribute to knowledge about gender, natural hazards and social vulnerability and aims to complement one aspect of gender studies linked to natural disasters, social vulnerability $[8,21,22]$. The literature related to the study of the SV of households is limited and 
even more so if it is linked to gender relations [21,22]. They are very scarce the work that analyzes whether or not women-led households are more vulnerable than those related to men and if this (inequality) in the SV increases as a result of the disaster.

This article has analyzed the effect on social vulnerability of one of the most devastating disasters of recent decades in the context of the poorest and most vulnerable country in Latin America and the Caribbean. We study how the 2010 earthquake in Haiti impacted the SV and the gender relations of Haitian households and show how gender inequalities persist and intensify after a disaster.

Investigating the relationship between poverty and disaster risk is a complex task, particularly in low-income territories where data scarcity is a common feature. From the data provided by the DHS survey and using the TOPSIS technique and the DID methodology we have been able to verify how the earthquake that hit Haiti in 2010 has negative effects on the SV of households, effects that intensify with the intensity of the disaster. In addition, we have been able to detect how the gender gap in the SV of households increases as a result of the disaster, increasing the SV of households headed by women in relation to other households.

The results derived from our research reaffirm those obtained in different studies that show how disasters do not produce equal consequences for the population as a whole, but that social and economic inequalities make certain groups more vulnerable[13,18,20]. Specifically, it reinforces studies that show how the disadvantages of post-disaster women persist are intensified in aspects such as education, life expectancy, sexual health, work, etc.[13,20,72,73].

These results generate important political implications that should not be ignored. The 2030 Agenda for Sustainable Development recognizes the strong relationship between gender equality, vulnerability and resilience to natural disasters, as well as the importance of this relationship for the achievement of the SDGs. The study shows how women and men face different realities and challenges in both pre-disaster and post-disaster. Their different position in the face of natural disasters is manifested in their sociodemographic characteristics, socioeconomic status and built environment, and they constitute key elements that affect their response and recovery capacity. Gender policies thus constitute a key element of the reduction of SV before, during and after the disaster. National and local programs are needed to improve disaster preparedness, mitigation and prevention in the community, with the participation of women and men, promoting gender equality and the empowerment of women.

The analysis carried out is established for the context of the 2010 Haiti earthquake. Similar studies would be necessary in other territories in order to find patterns of similarity and diversity in different environments.

Author Contributions: Conceptualization, M.L.-M., M.D.-F. and P.M.-R.; Methodology, M.L.-M., M.D.-F. and P.M.-R.; Software, P.M.-R.; Validation, M.L.-M.; Formal analysis, M.D.-F.; Investigation, R.G.A.; Data curation, M.L.-M. and P.M.-R.; Writing—original draft preparation, M.D.-F.; Writing-review and editing, M.L.-M., M.D.-F., P.M.-R. and R.G.A.; Visualization, P.M.-R. and R.G.A.; Supervision, M.L.-M. All authors have read and agreed to the published version of the manuscript.

Funding: This article is part of the GENDER Project (Gender, Disasters and Risks), FEM2017-86852-P, funded by the Spanish Research Agency.

Conflicts of Interest: The authors declare no conflict of interest.

\section{References}

1. Yang, W.; Xu, K.; Lian, J.; Ma, C.; Bin, L. Integrated flood vulnerability assessment approach based households on TOPSIS and Shannon entropy methods. Ecol. Indic. 2018, 89, 269-280. [CrossRef]

2. UNDRR—Oficina Regional de Las Américas y El Caribe. Available online: https:/eird.org/americas/noticias/ el-informe-de-evaluacion-global-sobre-la-reduccion-del-riesgo-de-desastres-2019.html\#.X1ZGPUp7m70 (accessed on 26 February 2020).

3. UNISDR. Terminology on Disaster Risk Reduction. Available online: https:/www.undrr.org/publication/ 2009-unisdr-terminology-disaster-risk-reduction (accessed on 12 February 2020).

4. Adger, W.N. Vulnerability. Glob. Environ. Chang. 2006, 16, 268-281. [CrossRef] 
5. Pérez de Armiño, K. Vulnerabilidad y desastres: Causas estructurales y procesos de la crisis de África. Cuad. Trab. Hegoa 2014, 24, 1-64.

6. Giovene di Girasole, E.; Cannatella, D. Social Vulnerability to Natural Hazards in Urban Systems. An Application in Santo Domingo (Dominican Republic). Sustainability 2017, 9, 2043. [CrossRef]

7. Dintwa, K.F.; Letamo, G.; Navaneetham, K. Measuring social vulnerability to natural hazards at the district level in Botswana. Jàmbá J. Disaster Risk Stud. 2019, 11. [CrossRef]

8. De Loyola Hummell, B.M.; Cutter, S.L.; Emrich, C.T. Social Vulnerability to Natural Hazards in Brazil. Int. J. Disaster Risk Sci. 2016, 7, 111-122. [CrossRef]

9. Thomas Bohórquez, J.E. Evaluación de la vulnerabilidad social ante amenazas naturales en Manzanillo (Colima). Un aporte de método. Investig. Geográficas Bol. Inst. Geogr. 2013, 79-93. [CrossRef]

10. Aptekar, L.; Boore, J. The Emotional Effects of Disaster on Children: A Review of the Literature. Int. J. Ment. Health 1990, 19, 77-90. [CrossRef]

11. Barnes, V.A.; Treiber, F.A.; Ludwig, D.A. African-American adolescents' stress responses after the 9/11/01 terrorist attacks. J. Adolesc. Health 2005, 36, 201-207. [CrossRef]

12. Peacock, W.G.; Morrow, B.H.; Gladwin, H. Hurricane Andrew: Ethnicity, Gender and the Sociology of Disasters; Routledge: London, UK; New York, NY, USA, 1997; ISBN 978-0-415-16811-3.

13. Bista, R.B. Determinants of Flood Disaster Households' Vulnerability in Nepal. Econ. J. Dev. Issues 2019, 47-59. [CrossRef]

14. Atlas of the Human Planet 2017: Global Exposure to Natural Hazards. Available online: https://ec.europa.eu/jrc/en/publication/eur-scientific-and-technical-research-reports/atlas-humanplanet-2017-global-exposure-natural-hazards (accessed on 13 February 2020).

15. Enarson, E. Gender and Natural Disasters. In Focus Programme on Crisis Response and Reconstruction, Working Paper 1; International Labour Organization: Geneva, Switzerland, 2000; ISBN 978-92-2-112260-9.

16. Enarson, E.; Meyreles, L. International perspectives on gender and disaster: Differences and possibilities. Int. J. Sociol. Soc. Policy 2004, 24, 49-93. [CrossRef]

17. Neumayer, E.; Plümper, T. The Gendered Nature of Natural Disasters: The Impact of Catastrophic Events on the Gender Gap in Life Expectancy, 1981-2002. Ann. Assoc. Am. Geogr. 2007, 97, 551-566. [CrossRef]

18. Horton, R. GBD 2010: Understanding disease, injury, and risk. Lancet 2012, 9859, 2053-2054. [CrossRef]

19. Faedi Duramy, B. Gender and Violence in Haiti: Women's Path from Victims to Agents; Rutgers University Press: New Brunswick, NJ, USA, 2014; ISBN 978-0-8135-6316-9.

20. Nelson, K.S.; Abkowitz, M.D.; Camp, J.V. A method for creating high resolution maps of social vulnerability in the context of environmental hazards. Appl. Geogr. 2015, 63, 89-100. [CrossRef]

21. Parida, P.K. The social construction of gendered vulnerability to tsunami disaster: The case of coastal Sri Lanka. J. Soc. Econ. Dev. 2015, 17, 200-222. [CrossRef]

22. Ahmad, A. Conceptualizing Disasters from a Gender Perspective. In Disasters: Core Concepts and Ethical Theories; O'Mathúna, D.P., Dranseika, V., Gordijn, B., Eds.; Advancing Global Bioethics; Springer International Publishing: Cham, Switzerland, 2018; Volume 11, pp. 105-117, ISBN 978-3-319-92722-0.

23. Rushton, A.; Gray, L.; Canty, J.; Blanchard, K. Beyond Binary: (Re)Defining "Gender" for 21st Century Disaster Risk Reduction Research, Policy, and Practice. Int. J. Environ. Res. Public. Health 2019, 16, 3984. [CrossRef]

24. Schonfeld, D.J.; Gurwitch, R.H. Addressing Disaster Mental Health Needs of Children: Practical Guidance for Pediatric Emergency Health Care Providers. Clin. Pediatr. Emerg. Med. 2009, 10, 208-215. [CrossRef]

25. Hamidazada, M.; Cruz, A.M.; Yokomatsu, M. Vulnerability Factors of Afghan Rural Women to Disasters. Int. J. Disaster Risk Sci. 2019, 10, 573-590. [CrossRef]

26. CEPALSTAT. Available online: https://cepalstat-prod.cepal.org/cepalstat/tabulador/ConsultaIntegrada.asp? idIndicador=2465\&idioma $=$ e (accessed on 10 February 2020).

27. Bradshaw, S.; Arenas, A. Análisis de Género en la Evaluación de los Efectos Socioeconómicos de los Desastres Naturales; Manuales; Naciones Unidas Comisión Económica para América Latina y el Caribe (CEPAL): Santiago, Chile, 2004.

28. Arenas Ferriz, A. Expert Group meeting on Enviromental management and mitigation of natural disasters: A gender perspective. In Proceedings of the Relevance of Considering a Gender Perspective in Damage Assessment and Recovery Strategies: A Case Study in El Salvador, Central America, Ankara, Turkey, 6-9 November 2001. 
29. PNUD: Sustainable Development Goals. Available online: https://www.undp.org/content/undp/es/home/ sustainable-development-goals.html (accessed on 11 February 2020).

30. Cutter, S.L. A research agenda for vulnerability science and environmental hazards. Int. Hum. Dimens. Program Update 2001, 1, 8-9.

31. Cutter, S.L.; Morath, D.P. The evolution of the Social Vulnerability Index. In Measuring Vulnerability to Natural Hazards; Birkmann, J., Ed.; United Nations University Press, forthcoming: Bonn, Germany, 2013; pp. 304-321.

32. Cutter, S.L.; Boruff, B.J.; Shirley, W.L. Social Vulnerability to Environmental Hazards. Soc. Sci. Q. 2003, 84, 242-261. [CrossRef]

33. Yeletaysi, S.; Ozceylan, D.; Fiedrich, F.; Harrald, J.R.; Jefferson, T. A framework to integrate social vulnerability into catastrophic natural disaster preparedness planning. In Proceedings of the International Emergency Management Society-TIEMS 16th Annual Conference, Istanbul, Turkey, 9-11 June 2009; pp. 9-11.

34. Chen, Y.; Boehm, B.W.; Sheppard, L. Value-Adaptive Security Threat Modeling and Vulnerability Ranking. U.S. Patent 8,392,997, 5 March 2013.

35. Cutter, S.L.; Finch, C. Temporal and spatial changes in social vulnerability to natural hazards. Proc. Natl. Acad. Sci. USA 2008, 105, 2301-2306. [CrossRef] [PubMed]

36. Borden, K.A.; Schmidtlein, M.C.; Emrich, C.T.; Piegorsch, W.W.; Cutter, S.L. Vulnerability of U.S. Cities to Environmental Hazards. J. Homel. Secur. Emerg. Manag. 2007, 4. [CrossRef]

37. Raschky, P. Institutions and the losses from natural disasters. Nat. Hazards Earth Syst. Sci. 2008, 8. [CrossRef]

38. Toya, H.; Skidmore, M. Economic development and the impacts of natural disasters. Econ. Lett. 2007, 94, 20-25. [CrossRef]

39. Kahn, M. The Death Toll from Natural Disasters: The Role of Income, Geography, and Institutions. Rev. Econ. Stat. 2005, 87, 271-284. [CrossRef]

40. Peduzzi, P.; Dao, H.; Herold, C.; Mouton, F. Assessing Global Exposure and Vulnerability towards Natural Hazards: The Disaster Risk Index. Nat. Hazards Earth Syst. Sci. 2009, 9, 1149-1159. [CrossRef]

41. Villagrán de León, J.C. Vulnerability: A Conceptual and Methodological Review; United Nationas University, Institute for Environment and Human Security: Bonn, Germany, 2006; ISBN 978-3-9810582-4-6.

42. Angeon, V.; Bates, S. Reviewing Composite Vulnerability and Resilience Indexes: A Sustainable Approach and Application. World Dev. 2015, 72, 140-162. [CrossRef]

43. Cutter, S.L.; Boruff, B.J.; Shirley, W.L. Social vulnerability to environmental hazards. In Hazards Vulnerability and Environmental Justice; Routledge: Londres, UK, 2012; pp. 143-160.

44. Dwyer, A.; Zoppou, C.; Nielsen, O.; Day, S.; Roberts, S. Quantifying Social Vulnerability: A Methodology for Identifying Those at Risk to Natural Hazards; Geoscience Australia: Canberra, Australia, 2004; ISBN 978-1-920871-09-3.

45. Welle, T.; Birkmann, J. The World Risk Index-An Approach to Assess Risk and Vulnerability on a Global Scale. J. Extrem. Events 2015, 2, 1550003. [CrossRef]

46. Hwang, C.-L.; Yoon, K. Multiple Attribute Decision Making: Methods and Applications A State-of-the-Art Survey; Lecture Notes in Economics and Mathematical Systems; Springer: Berlin/Heidelberg, Germany, 1981; ISBN 978-3-540-10558-9.

47. Behzadian, M.; Khanmohammadi Otaghsara, S.; Yazdani, M.; Ignatius, J. A state-of the-art survey of TOPSIS applications. Expert Syst. Appl. 2012, 39, 13051-13069. [CrossRef]

48. Zyoud, S.H.; Fuchs-Hanusch, D. A bibliometric-based survey on AHP and TOPSIS techniques. Expert Syst. Appl. 2017, 78, 158-181. [CrossRef]

49. USGS. English: Shake Map of 2010 Haiti Earthquake. 2010. Available online: https://earthquake.usgs.gov/ earthquakes/eventpage/usp000h60h/shakemap/intensity (accessed on 25 February 2020).

50. Kolbe, A.R.; Hutson, R.A.; Shannon, H.; Trzcinski, E.; Miles, B.; Levitz, N.; Puccio, M.; James, L.; Noel, J.R.; Muggah, R. Mortality, crime and access to basic needs before and after the Haiti earthquake: A random survey of Port-au-Prince households. Med. Confl. Surviv. 2010, 26, 281-297. [CrossRef] [PubMed]

51. Doocy, S.; Cherewick, M.; Kirsch, T. Mortality following the Haitian earthquake of 2010: A stratified cluster survey. Popul. Health Metr. 2013, 11, 5. [CrossRef] [PubMed]

52. Roberts, R. Responding in a Crisis: The Role of National and International Health Workers—Lessons from Haiti; Merlin: London, UK, 2010.

53. Human Rights Watch (Organization). 2011 Human Rights Watch World Report: Strategies to Save the Planet; Seven Stories; Turnaround Distributor: New York, NY, USA; London, UK, 2011; ISBN 978-1-58322-921-7. 
54. Human Development Index (HDI). Human Development Reports. Available online: http://hdr.undp.org/en/ content/human-development-index-hdi (accessed on 25 February 2020).

55. Ministry of Public Health and Population [le Ministère de la Santé Publique and de la Population] (MSPP); Haitian Childhood Institute [1'Institut Haïtien de l’Enfance] (IHE); ICF International. 2012 Haïti Mortality, Morbidity, and Service Utilization Survey: Key Findings; MSPP, IHE, and ICF International: Calverton, MD, USA, 2013.

56. Cayemittes, M.; Placide, M.F.; Mariko, S.; Barrère, B.; Sévère, B.; Alexandre, C. Enquête Mortalité, Morbidité et Utilisation des Services: EMMUS-IV: Haïti: 2005-2006. Available online: http://bases.bireme.br/cgi-bin/wxislind.exe/iah/online/?IsisScript=iah/iah.xis\&src=google\&base $=$ DESASTRES\&lang=p\&nextAction=lnk\&exprSearch=18482\&indexSearch=ID (accessed on 10 April 2020).

57. Schmidtlein, M.C.; Deutsch, R.C.; Piegorsch, W.W.; Cutter, S.L. A Sensitivity Analysis of the Social Vulnerability Index. Risk Anal. 2008, 28, 1099-1114. [CrossRef] [PubMed]

58. Adger, W.N.; Brooks, N.; Bentham, G.; Agnew, M.; Eriksen, S. New Indicators of Vulnerability and Adaptive Capacity; Technical Report 7; Tyndall Centre for Climate Change Research, University of East Anglia: Norwich, UK, 2004.

59. Fekete, A. Validation of a social vulnerability index in context to river-floods in Germany. Nat. Hazards Earth Syst. Sci. 2009, 9, 393-403. [CrossRef]

60. Rygel, L.; O'sullivan, D.; Yarnal, B. A Method for Constructing a Social Vulnerability Index: An Application to Hurricane Storm Surges in a Developed Country. Mitig. Adapt. Strat. Glob. Chang. 2006, 11, 741-764. [CrossRef]

61. de Oliveira Mendes, J.M. Social vulnerability indexes as planning tools: Beyond the preparedness paradigm. J. Risk Res. 2009, 12, 43-58. [CrossRef]

62. Wood, N.J.; Burton, C.G.; Cutter, S.L. Community variations in social vulnerability to Cascadia-related tsunamis in the U.S. Pacific Northwest. Nat. Hazards 2010, 52, 369-389. [CrossRef]

63. Finch, C.; Emrich, C.T.; Cutter, S.L. Disaster disparities and differential recovery in New Orleans. Popul. Environ. 2010, 31, 179-202. [CrossRef]

64. Armas, I.; Gavriș, A. Social vulnerability assessment using spatial multi-criteria analysis (SEVI model) and the Social Vulnerability Index (SoVI model)—A case study for Bucharest, Romania. Nat. Hazards Earth Syst. Sci. 2013, 13, 1481-1499. [CrossRef]

65. Martins, V.N.; e Silva, D.S.; Cabral, P. Social vulnerability assessment to seismic risk using multicriteria analysis: The case study of Vila Franca do Campo (São Miguel Island, Azores, Portugal). Nat. Hazards 2012, 62, 385-404. [CrossRef]

66. Ouma, Y.O.; Tateishi, R. Urban Flood Vulnerability and Risk Mapping Using Integrated Multi-Parametric AHP and GIS: Methodological Overview and Case Study Assessment. Water 2014, 6, 1515-1545. [CrossRef]

67. Song, J.Y.; Chung, E.-S. Robustness, Uncertainty and Sensitivity Analyses of the TOPSIS Method for Quantitative Climate Change Vulnerability: A Case Study of Flood Damage. Water Resour. Manag. 2016, 30, 4751-4771. [CrossRef]

68. Chung, E.S.; Abdulai, P.J.; Park, H.; Kim, Y.; Ahn, S.R.; Kim, S.J. Multi-Criteria Assessment of Spatial Robust Water Resource Vulnerability Using the TOPSIS Method Coupled with Objective and Subjective Weights in the Han River Basin. Sustainability 2017, 9, 29. [CrossRef]

69. Bae, H.J.; Kang, J.E.; Lim, Y.R. Assessing the Health Vulnerability Caused by Climate and Air Pollution in Korea Using the Fuzzy TOPSIS. Sustainability 2019, 11, 2894. [CrossRef]

70. Shih, H.S.; Shyur, H.J.; Lee, E.S. An extension of TOPSIS for group decision making. Math. Comput. Model. 2007, 45, 801-813. [CrossRef]

71. Abo-Sinna, M.A.; Amer, A.H. Extensions of TOPSIS for multi-objective large-scale nonlinear programming problems. Appl. Math. Comput. 2005, 162, 243-256. [CrossRef]

72. Huang, Y.-S.; Li, W.-H. A Study on Aggregation of TOPSIS Ideal Solutions for Group Decision-Making. Group Decis. Negot. 2012, 21, 461-473. [CrossRef]

73. Govindan, K.; Khodaverdi, R.; Jafarian, A. A fuzzy multi criteria approach for measuring sustainability performance of a supplier based on triple bottom line approach. J. Clean. Prod. 2013, 47, 345-354. [CrossRef]

74. Lixin, Y.; Ke, C.; Xiaoying, C.; Yueling, S.; Xiaoqing, C.; Ye, H. Analysis of social vulnerability of residential community to hazards in Tianjin, China. Nat. Hazards 2017, 87, 1223-1243. [CrossRef] 
75. Schlotter, M.; Schwerdt, G.; Woessmann, L. Econometric methods for causal evaluation of education policies and practices: A non-technical guide. Educ. Econ. 2011, 19, 109-137. [CrossRef]

76. Wooldridge, J.M. Econometric Analysis of Cross Section and Panel Data, 2nd ed.; MIT Press: Cambridge, MA, USA, 2010; ISBN 978-0-262-23258-6.

77. Weitzman, A.; Behrman, J.A. Disaster, Disruption to Family Life, and Intimate Partner Violence: The Case of the 2010 Earthquake in Haiti. Sociol. Sci. 2016, 3, 167-189. [CrossRef]

78. USGS. the Modified Mercalli Intensity (MMI) Scale assigns intensities as. Available online: https://www.usgs. gov/media/images/modified-mercalli-intensity-mmi-scale-assigns-intensities (accessed on 11 April 2020).

79. OECD; European Union; Joint Research Centre. European Commission Handbook on Constructing Composite Indicators: Methodology and User Guide; OECD: Paris, France, 2008; ISBN 978-92-64-04345-9.

80. Cutter, S.L. GI science, disasters, and emergency management. Trans. GIS 2003, 7, 439-446.

81. De Silva, M.M.G.T.; Kawasaki, A. Socioeconomic Vulnerability to Disaster Risk: A Case Study of Flood and Drought Impact in a Rural Sri Lankan Community. Ecol. Econ. 2018, 152, 131-140. [CrossRef]

(C) 2020 by the authors. Licensee MDPI, Basel, Switzerland. This article is an open access article distributed under the terms and conditions of the Creative Commons Attribution (CC BY) license (http://creativecommons.org/licenses/by/4.0/). 